\title{
Current Overview of Idiopathic Intracranial Hypertension
}

\author{
İdyopatik İntrakraniyal Hipertansiyona Yaklaşımda Güncel Bakış
}

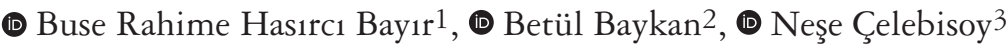 \\ 1 University of Health Sciences Turkey, Haydarpasa Numune Training and Research Hospital, Istanbul, Turkey \\ 2Istanbul University, Istanbul Faculty of Medicine, Department of Neurology, Istanbul, Turkey \\ ${ }^{3}$ Ege University Faculty of Medicine, Department of Neurology, Izmir, Turkey
}

\begin{abstract}

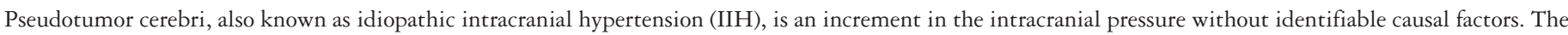

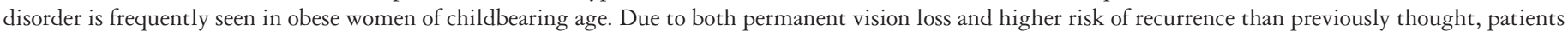

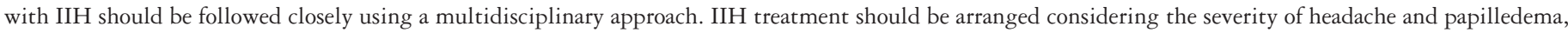

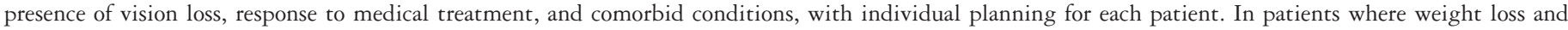

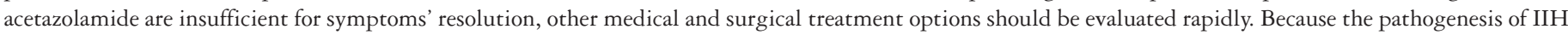

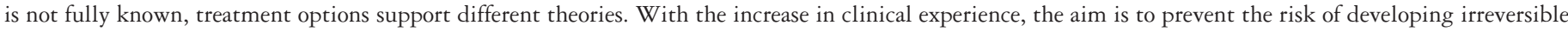

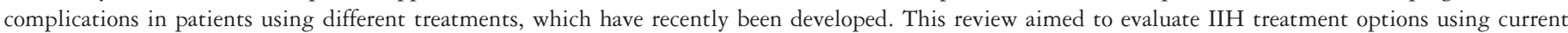
approaches and help physicians in the decision-making process.
\end{abstract}

Keywords: Pseudotumor cerebri, idiopathic intracranial hypertension, medical, surgical, treatment

$\ddot{O} \mathbf{z}$

Sıklıkla doğurganlık çă̆ındaki obez kadınlarda görülen, "psödotümör serebri” ya da diğer adıyla "idyopatik intrakraniyal hipertansiyon (İIH)” tanımlanabilir nedensel faktörler olmaksızın görülen intrakraniyal basınç artışıdır. Hem kalıcı görme kaybı hem de sanılandan yüksek nüks riski nedeniyle İIH'li hastalar multidispliner bir yaklaşımla, uzun süre yakından takip edilmelidir. Her hasta için yapılacak bireye özgü planlama ile baş ağrısı ve papilödemin şiddeti, görme kaybının varlığ $\breve{s}_{1}$ tıbbi tedaviye alınan yanıt ve komorbid durumlar göz önünde bulundurularak İ̇̇H tedavisi düzenlenmelidir. Kilo verme ve asetozolamid ile yeterli fayda görülemediği durumlarda hızla diğer medikal ve izleyen dönemde cerrahi tedavi seçenekleri değerlendirilmelidir. İIH'nin patogenezi tam olarak

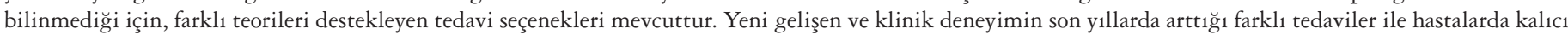
komplikasyonların gelişme riskinin önüne geçilmeye çalışılmaktadır. Bu derlemenin amacı İIHH tedavisindeki seçeneklerin güncel yaklaşımlar ile değerlendirilmesi ve klinisyene karar verme sürecinde yardımcı olabilmesidir.

Anahtar Kelimeler: Psödotümör serebri, idyopatik intrakraniyal hipertansiyon, medikal, cerrahi, tedavi

\section{Introduction}

Pseudotumor cerebri or idiopathic intracranial hypertension (IIH) is an increase in intracranial pressure without identifiable causal factors, such as a space-occupying lesion, infection, or malignancy. Increased intracranial pressure (IIP) may develop due to primary or secondary causes. IIH is strongly associated with female gender and obesity. However, the reason for the IIP is not yet known. It is hoped that, in the near future, studies on genetic, immunological, and other mechanisms may explain the etiology of this disorder (1).

IIH can cause severe deficits, such as permanent vision loss, and have a high risk of recurrence. In this review, we emphasized the treatment methods, which can be selected according to the presence and degree of symptoms, and the importance of these

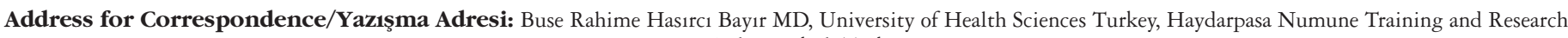
Hospital, Istanbul, Turkey

Phone: +90 5368984475 E-mail: busehasirci@yahoo.com ORCID: orcid.org/0000-0001-5740-8822

Received/Geliş Tarihi: 06.02.2021 Accepted/Kabul Tarihi: 17.05.2021

${ }^{\oplus}$ Copyright 2021 by Turkish Neurological Society

Turkish Journal of Neurology published by Galenos Publishing House. 
choices and follow-up, using a multidisciplinary approach, involving neuroophthalmology, neurosurgery, and, especially, neurology., The rate of treatment success is expected to increase with correct diagnosis, appropriate treatment, and regular follow-up.

\section{Clinical Features and Incidence}

Common symptoms of IIH, mostly seen in obese women of childbearing age, include headache, transient vision loss, and pulsatile tinnitus. Headache with a progressive course is the most common finding and is more prominent, especially, in the morning hours and when lying in a supine position. Since it develops due to IIP, nausea and vomiting may accompany the headache, and it may worsen with coughing and Valsalva maneuver. IIH does not have a unique headache character and headache can occur in different forms, such as stabbing headache, trigeminal neuralgia, and radicular pain. The headache varies according to the underlying primary headache phenotype of the patient (2). Headaches in IIH often resembles tension-type headaches with their bilateral, frontal, and retroocular localization, but unilateral, throbbing, migraine-type headache features, accompanied by nausea and photophobia, are observed in $70 \%$ of patients (3). While, in some patients, the episodic headache turns into a chronic daily headache, a new headache with different characteristics may occur. It should be noted that allodynia, a clinical marker of central sensitization, could be seen in IIH. The relationship between allodynia and IIH was shown for the first time in a study by Ekizoglu et al. (4). It is known that, in some patients, headaches may continue, although it is expected that the cerebrospinal fluid (CSF) opening pressure will return to normal, and a complete recovery from headaches can be expected (5).

Pulsatile tinnitus, which can be unilateral or bilateral, occurs due to transverse sinus stenosis, which causes turbulence in the blood flow (6). In an IIH treatment study, including 165 patients, it was reported that $84 \%$ of the patients had headaches, $68 \%$ had a temporary vision loss, and $52-60 \%$ had pulsatile tinnitus at the time of admission (7).

Papilledema is the most important clinical finding in IIH. It is often bilateral and symmetric (8). Disruption of the axoplasmic flow due to increased ICP causes edema in the retinal nerve fibers emerging from the optic disc. There is a direct correlation between the severity of papilledema and prognosis of vision (9). If left untreated, it can cause progressive and irreversible vision loss, resulting in optic atrophy (10). Transient visual loss, due to a transient ischemia of the edematous optic nerve head, is associated with severe papilledema. After a few seconds of partial or complete loss of vision, the vision returns to its original state (10). In partial or complete abducens palsy, the most common finding is horizontal diplopia, which worsens when looking away from the near (1).

Contrary to popular belief, the course of IIH is not always monophasic and may progress with relapses. In a study by Tata et al. (11), recurrence was observed in $23 \%$ of patients $(n=75)$ with $\mathrm{IIH}$, and no relationship was found between the demographic and clinical characteristics and risk of recurrence. In a study including 65 patients, it was reported that relapses were seen at a rate of $23 \%$ in children, especially one year after treatment cessation, and at a rate of $50 \%$ in adolescents and $28 \%$ in adults on an average of three years after drug discontinuation (12). In IHH, patients' follow-ups are long due to the risk of recurrence. Follow-ups are recommended to continue for a long time, or even for a lifetime.
In patients with preexisting headaches, headaches that continue after IIH goes into remission cause difficulties in the follow-ups, and headaches may continue in patients who did not experience headaches before, despite ICP control. Pressure increase with lumbar puncture (LP) or the reappearance of papilledema is valuable for the diagnosis of recurrence.

Different incidences have been attributed to the variability of obesity prevalence worldwide (13). The incidence in western societies is $0.9 / 100,000 /$ year. In the female population in the age group of 15-44 years, this rate rises to 3.5/100,000. On considering women aged $20-44$ years, who are $20 \%$ above their ideal weight, this rate rises to $19 / 100,000 /$ year (14). The incidence of $\mathrm{IHH}$ is 10 times more in America than Asia. However, it has not yet been studied in Turkey.

\section{Primary IIH diagnostic Criteria}

The pseudotumor cerebri syndrome gathers all similar clinical presentations under one roof, and recently, its diagnosis has been used more frequently to eliminate terminological confusion with its primary and secondary subheadings (1). Although establishing the diagnosis of "IIH without papilledema" is an important breakthrough, it is increasingly overused and misused. Additionally Friedman et al. (1) revised the diagnostic criteria to increase awareness of the neuroradiological findings of the disorder (Table 1). For a definitive diagnosis, the patient must meet criteria A-E. For a probable diagnosis, the CSF pressure is lower than that indicated for definitive diagnosis, and the patient must meet criteria A-D.

\section{CSF Findings}

With LP, the high CSF opening pressure, which is necessary for the diagnosis of IIH, is determined, and secondary causes, which may cause intracranial pressure, are excluded. In adults, the normal $\mathrm{CSF}$ opening pressure is $10-20 \mathrm{~cm} \mathrm{H}_{2} \mathrm{O}$. The limit value between 20 and $25 \mathrm{~cm} \mathrm{H}_{2} \mathrm{O}$ and values above $25 \mathrm{~cm} \mathrm{H}_{2} \mathrm{O}$ are considered high CSF opening pressure. CSF white cell count and glucose and protein concentrations should be normal in patients with IIH (10).

\section{Diagnostic Advances in Radiology}

Due to the risk of permanent vision loss in IIH, the need for early diagnosis is increasingly important, especially in patients with chronic headache without papilledema. Neuroradiological findings in patients whose clinical findings are insufficient facilitate the correct diagnosis. An empty sella, flattening of the posterior globe, transverse venous sinus stenosis, and enlargement of the perioptic subarachnoid space are neuroradiological findings seen in IIH (Figure 1a, b, c, d). In a study by Mallery et al. (15), the sensitivity and specificity of the diagnosis in the presence of radiological findings were evaluated (Table 2).

In an important study by Bono et al. (16), a high CSF opening pressure was in two-thirds of patients with bilateral transverse sinus stenosis, chronic migraines, and chronic tension-type headaches, and they were diagnosed with IIH. While the presence of neuroradiological findings in IIH supports the diagnosis, their absence does not exclude the diagnosis. Patients with IIH may have normal neuroradiological findings (5).

\section{Investigating the Causes of Secondary IIH}

Since the treatment of IIH due to secondary causes targets the underlying cause, the causes that may lead to ICP should be evaluated in detail before primary IIH is diagnosed (Table 3). 
Table 1. Recommended Friedman diagnostic criteria for pseudotumor cerebri syndrome (1)

1. These are necessary for the diagnosis of pseudotumor cerebri syndrome:

A. Papilledema,

B. Normal neurologic examination findings-except cranial nerve abnormalities,

C. Normal neuroimaging findings: Absence of hydrocephalus, mass, structural lesion and abnormal meningeal involvement in MRI with or without contrast. Normal MRI and MR venography with or without contrast if patient is not obese and female,

D. Normal CSF composition,

E. Increased CSF opening pressure $\left(\geq 250 \mathrm{mmH}_{2} \mathrm{O}\right)$ with appropriately performed LP

2. For the diagnosis of pseudotumor cerebri syndrome without papilledema:

Unilateral or bilateral abducens nerve paralysis along with criteria B-E must be fulfilled

If there is no papilledema or $6^{\text {th }}$ cranial nerve paralysis, PTCS diagnosis can be suggested, but a definite diagnosis cannot be made In order to be able to recommend a PTCS diagnosis, there should be at least 3 of the following MRI findings in addition to criteria B-E:

i. Empty sella,

ii. Posterior globe flattening,

iii. Distension of perioptic subarachnoid space (may or may not be accompanied by tortuous optic nerve),

iv. Transverse venous sinus stenosis

MRI: Magnetic resonance image, CSF: Cerebrospinal fluid, LP: Lumbar puncture, PTCS: Pseudotumor cerebri syndrome

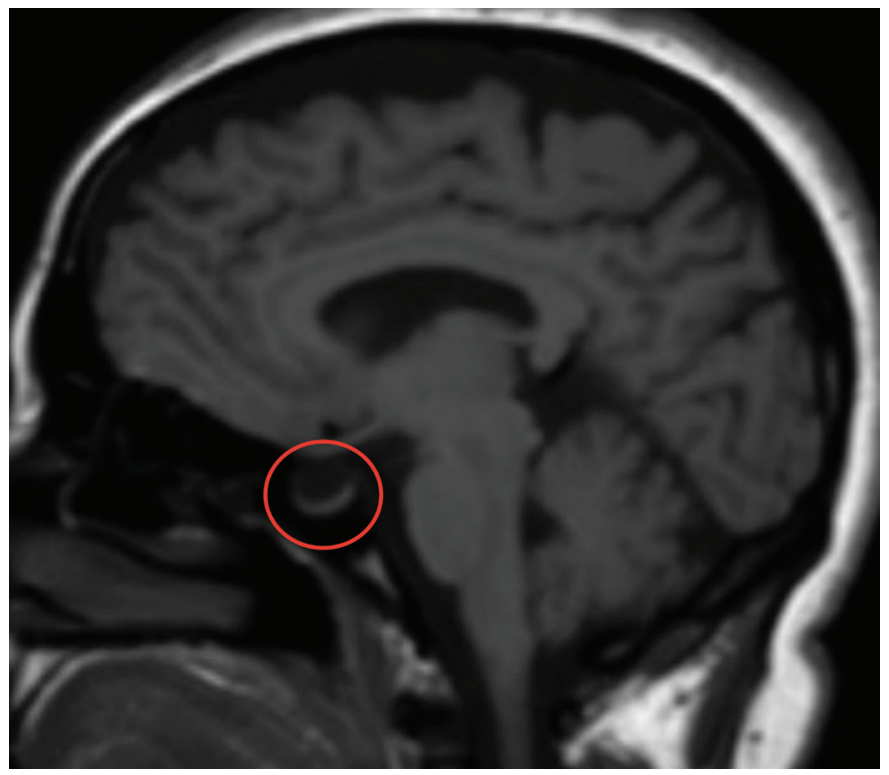

Figure 1a. Empty sella

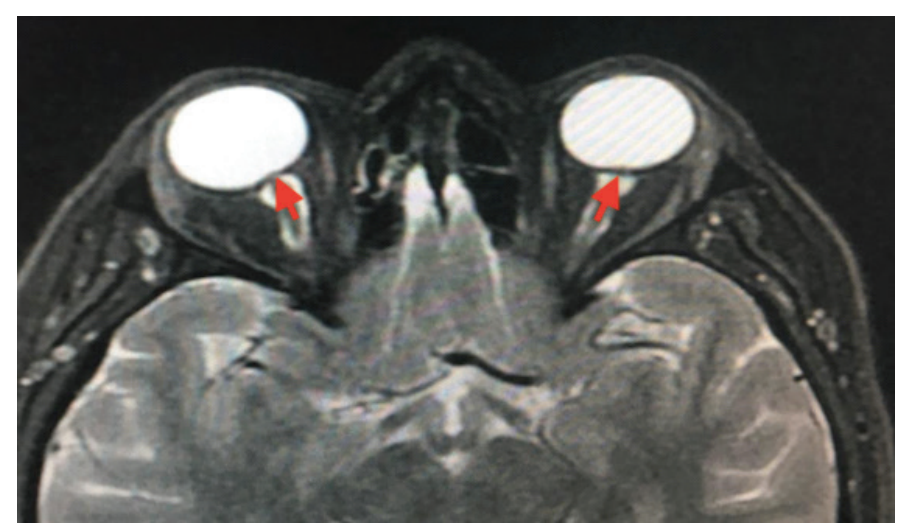

Figure 1b. Posterior globe flattening

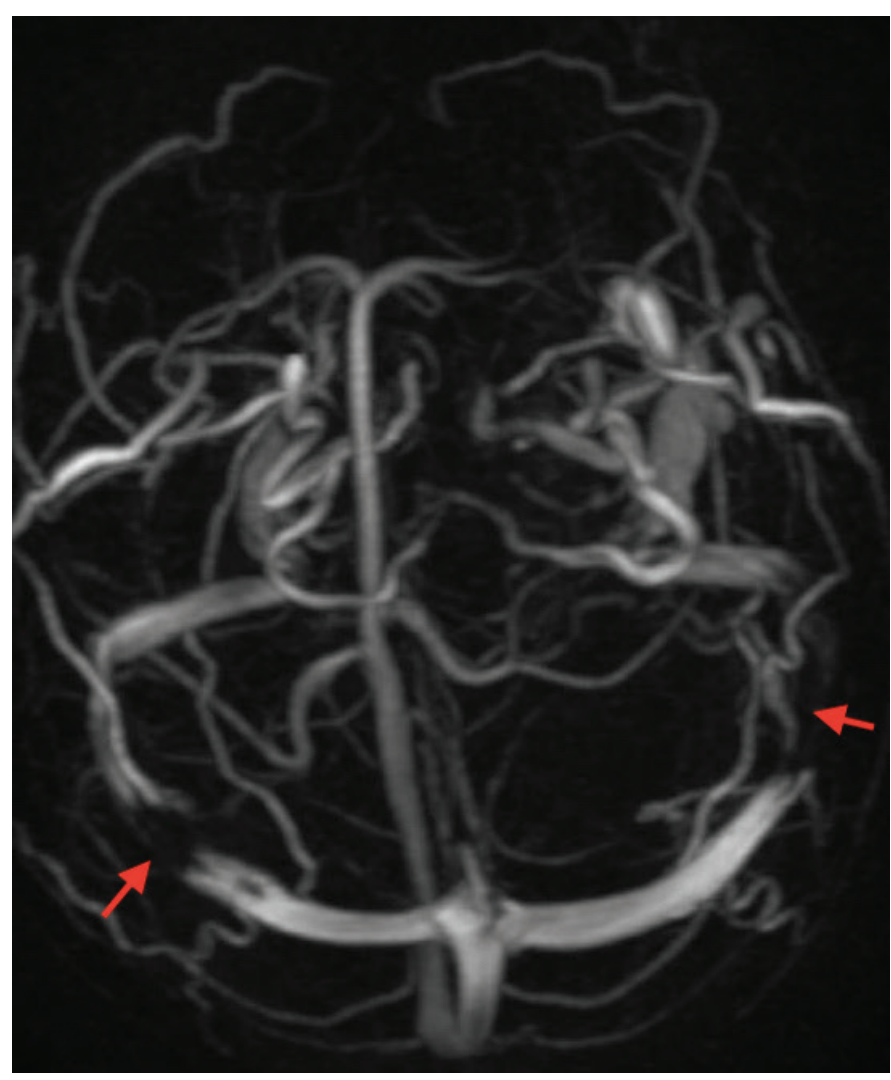

Figure 1c. Bilateral transverse venous sinus stenosis

\section{Current Approach in Treatment}

Although IIH has been known for decades, there is no consensus about its exact cause, and a treatment algorithm, highlighting which treatment to start, when to start, and how long to continue, does not exist (17). The treatment options, including weight loss, medical treatment, and surgical interventions (Figure 2), 


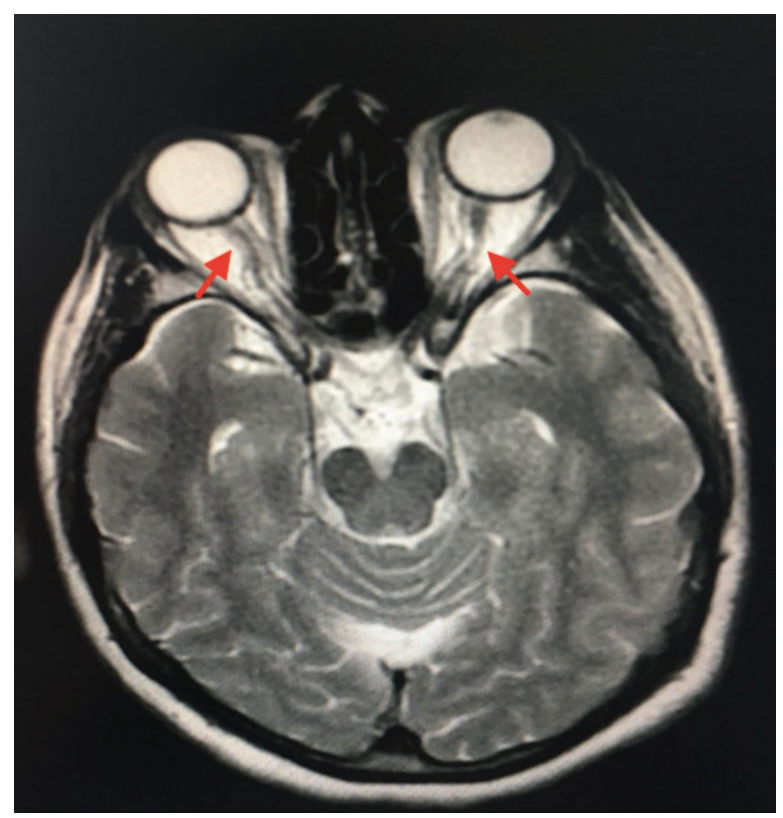

should be evaluated individually for each patient, according to the presence, degree, and rate of development of vision loss, severity of headache and papilledema, response to medical treatment, comorbid conditions, and tolerability of treatment.

\section{Conservative treatment}

\section{Weight control:}

The purpose of using body mass index (BMI), which has been used since the $19^{\text {th }}$ century, is to identify individuals with abnormal weight in proportion to their height, when IIH has been recognized. BMI is calculated by dividing the weight in kilograms (kg) by the height in square meters $\left(\mathrm{m}^{2}\right)$ and is universally expressed in $\mathrm{kg} / \mathrm{m}^{2}$ (Table 4) (18).

Obesity was found in $90 \%$ of patients with $\mathrm{IIH}$. There is an unknown relationship between IIH and obesity, especially in women (19). Generally, high-grade papilledema and more severe vision loss are expected in patients with a BMI greater than $40 \mathrm{~kg} /$ $\mathrm{m}^{2}$ (20). The view that, in $\mathrm{IHH}$, the adipose tissue has endocrinelike functions may be explained by hypothalamic leptin resistance, increased chemokine levels in both serum and CSF samples of patients, and increased levels of proinflammatory cytokines and

Figure 1d. Tortuous optic nerve

Table 2. Sensitivity and specificity of radiological findings in IIH

\begin{tabular}{lll} 
Radiological findings of idiopathic intracranial hypertension & Sensitivity (\%) & Specificity (\%) \\
Empty sella & 80 & 64 \\
Posterior globe flattening & 57 & 97 \\
Tortuous optic nerve & 51 & 83 \\
Transverse venous sinus stenosis & 78 & - \\
In a patient with chronic headache without papilledema: If 3 out of 4 findings are present & 64 & $97-100$ \\
"Adapted from reference 15, IIH: Idiopathic intracranial hypertension & & \\
\hline
\end{tabular}

\section{Table 3. Causes of secondary IIH}

\section{Drugs:}

- Antibiotics (tetracycline, doxycycline, nalidixic acid)

- Vitamin-A and retinoids

- Lithium

- Hormones (growth hormone, thyroxine use in children, anabolic steroids)

- Withdrawal of corticosteroids

Medical conditions:

- Endocrinological diseases (Addison, hypoparathyroidism)

- Kidney failure

- Anemia

- Down syndrome

- Turner syndrome

- Hypercapnia (obstructive sleep apnea-Pickwick syndrome)

Cerebral venous pathologies:

- Cerebral venous sinus thrombosis

- Bilateral jugular vein thrombosis

- Middle ear infection or mastoiditis

- Central venous hypertension due to heart failure

- Superior vena cava syndrome

- Arterio-venous fistulas

- Conditions that cause hypercoagulability

- Decreased CSF absorption due to previous intracranial infection or subarachnoid hemorrhage

IIH: Idiopathic intracranial hypertension, CSF: Cerebrospinal fluid 
interleukins 2 and 17 in CSF (21). The theory that the relationship between obesity and IIH exists because of the mechanical effects of abdominal adiposity alone is insufficient to explain why $\mathrm{IIH}$ develops in only some obese patients (21). Additionally, there is no relationship between BMI and CSF opening pressure (22).

Studies and clinical observations on the effectiveness of weight control in IIH strongly support weight loss as an effective treatment. With a $6-10 \%$ loss of the current weight, clinical improvement is observed in various parameters, including ICP, papilledema, and headache (20,23). While, with the patient's

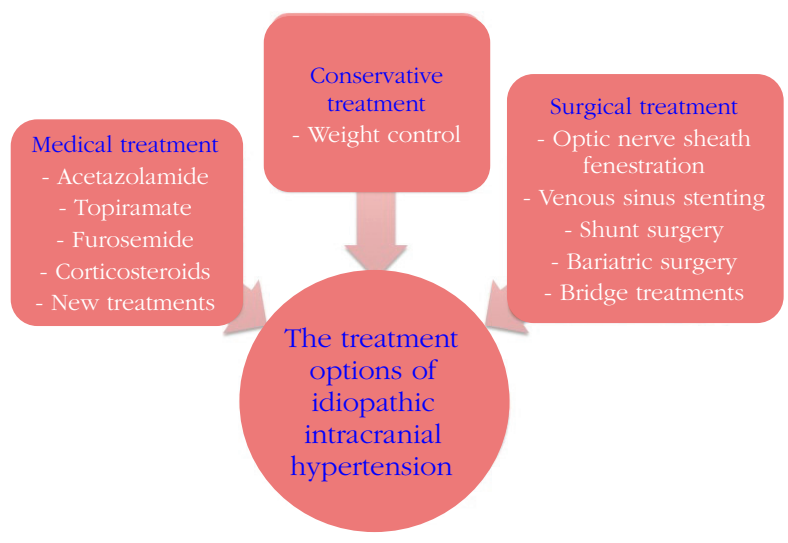

Figure 2. Treatment options in idiopathic intracranial hypertension

\begin{tabular}{|ll|}
\hline $\begin{array}{l}\text { Table 4. World Health } \\
\text { classification }\end{array}$ & Organization body-mass index \\
\hline Weight & Body mass index $\left(\mathrm{kg} / \mathrm{m}^{2}\right)$ \\
Underweight & $<18.5$ \\
Normal & $18.5-24.9$ \\
Overweight & $25.0-29.9$ \\
Obese & $\geq 30$ \\
- Class 1 obese & $30.0-34.9$ \\
- Class 2 obese & $35.0-39.9$ \\
- Class 3 obese & $\geq 40$ \\
\hline
\end{tabular}

own motivation, a $5 \%$ weight loss within a year is realized at the level of $20-35 \%$, it reaches $50-70 \%$ with professional support accompanied by lifestyle changes. While only one-third of the patients can maintain the weight they have lost in the long term, they often return to their previous weight within one to three years (20). In non-obese patients, a $5 \%$ or more of weight gain, close to the onset of symptoms, increases the risk of IIH (24). Although the IIH findings have completely resolved, it has been reported that the risk of recurrence increases with an average weight gain of $6 \%$, and the $\mathrm{BMI}$ at the time of recurrence is often higher than at the initial diagnosis $(25,26)$.

Since many obese patients with IIH often have lifelong weight problems, it is difficult to maintain weight loss during treatment. The decrease in exercise capacity in patients with severe headaches creates a separate difficulty in maintaining weight control (26). Therefore, in patients with high BMI, the development of strategies for weight loss should be started at the patient's first presentation, and they should be carefully and repeatedly instructed that weight control is one of the most important treatment steps.

\section{Medical Treatment}

Medical treatment options should be considered in normalweight patients with IIH or when the diet alone is insufficient. Besides preserving the main purpose of visual functions, medical treatments can also control the headaches.

\section{a. Acetazolamide:}

Acetazolamide, a potent carbonic anhydrase enzyme inhibitor, acts by reducing CSF secretion from the choroid plexuses. Since the 1970 s, it has been used worldwide for treating PTSS, with doses up to $4 \mathrm{~g}$ per day, which vary according to the need (27). Its effect on visual functions was first proven in the randomized controlled, prospective "Idiopathic Intracranial Hypertension Treatment Study" conducted in 2014. The study included 165 patients (161 were female) with a mild vision loss and mean age of 29 years; they were given a low-sodium diet. The patients were divided into two groups: Group 1 took acetazolamide in addition to the diet, and group 2 (placebo) adhered to the diet and received no medications. Among the patients targeting to lose $6 \%$ of their body weight within six months, those who took acetazolamide in addition to the diet had a higher reduction in the degree of papilledema and

Table 5. Comparison of surgical interventions

$\begin{array}{lllll} & \text { ONSF } & \text { VSS } & \text { Vp-Lp shunt } & \text { Bariatric surgery } \\ \text { Number of studies } & 23 & 47 & 28 & 11 \\ \text { Number of patients } & 818(1.365 \text { eyes) } & 825 & 609 & 50 \\ \text { - Female patient ratio (\%) } & 88 & 82 & 88 & 100 \\ \text { - Obesity (\%) } & 86 & 64 & 73 & 100 \\ \text { Follow up duration (months/mean) } & 41(0-278) & 20(0-136) & 41(0-278) & 43(4-168) \\ \text { Age (years/mean) } & 33(4-68) & 37(10-66) & 33(4-68) & 34(15-53) \\ \text { Recovery rates (\%) } & 67 & & 67 & 83 \\ \text { - Visual field } & 55 & 73 & 55 & 100 \\ \text { - Visual acuity } & 70 & 75 & 70 & 93 \\ \text { - Headache } & 79 & 87 & 79 & 100 \\ \text { - Papiledema } & 9 & 12 & 43 & 7 \\ \text { Failure rates (\%) } & 95 & \\ \text { *Adapted from reference 53. ONSF: Optic nerve sheath fenestration, Lp: Lumboperitoneal, Vp: Ventriculoperitoneal, vss: Venous sinus stenting }\end{array}$


improvement in visual field functions compared with those who adhered to the diet and received no medications (28).

Although the optimal dose has not been determined, 250$500 \mathrm{mg}$ twice daily is often preferred as a starting dose. The maintenance treatment is continued with 1-2 g daily. Due to side effects such as paresthesia, nausea, vomiting, and diarrhea, a maximum daily dose of $4 \mathrm{~g}$ is hardly tolerated by patients $(28,29)$.

Since IIH often affects women of childbearing age, it is important to inform them about the teratogenic side effects of acetazolamide, which is classified as category C. Although its teratogenic effects were observed in experimental animals, data obtained from 158 pregnancies of 101 patients, who used this drug both before and during pregnancy, showed that the risk of spontaneous abortion was the same as in the control group, and no major complications developed in newborns (30).

\section{b. Topiramate:}

Topiramate can be used as a monotherapy or add-on therapy in patients where acetazolamide cannot be used or in acetazolamideresistant headaches. Moreover, it acts as both a voltage-gated sodium and calcium channel inhibitor and a weak carbonic anhydrase inhibitor. In a study by Çelebisoy et al. (31), in the follow-up period of 40 patients, who were given acetazolamide or topiramate, a visual field improvement was detected with both treatments, and no significant difference was observed between both drugs. Daily use of 100-150 mg of topiramate is equivalent to the efficacy of 1000-1500 mg of acetazolamide when used daily. When treating IIH, the side effect of weight loss is used, and other side effects are similar to those of acetazolamide (19). Being an effective prophylaxis option in migraine, topiramate increases the rate of patients who benefit (32).

\section{c. Furosemide:}

Furosemide (used in a low-to-medium dose) can be added to acetazolamide because of its diuretic effect. Since there is insufficient clinical evidence regarding the treatment of $\mathrm{IIH}$, it is not recommended to be used as monotherapy. During the treatment period, regular monitoring of electrolytes and potassium supplementation are required (33).

\section{d. Corticosteroids:}

Today, corticosteroids are not routinely used for treating IIH due to undesirable side effects, such as weight gain (27). However, high-dose steroid use may be preferred in patients with rapidly progressive vision loss and in patients with fulminant IIH, awaiting surgical treatment (34).

\section{e. New options on the horizon:}

New treatments, which will reduce ICP faster than the existing methods, are being studied. Glucagon-like peptide-1 (GLP-1) regulates insulin secretion and is used for treating diabetes (21). Exendin-4, a GLP-1 receptor agonist, reduces ICP in in vitro studies (35).

The 11-beta hydroxysteroid dehydrogenase type-1 (11 $\beta$-HSD1) converts inactive cortisone to active cortisol and regulates the local cortisol level, which plays a decisive role in fluid secretion (36). It is released from the choroid plexus and affects CSF production through cortisol levels (37). 11 $\beta$-HSD1 levels were decreased in patients, whose ICP decreased and headache and papilledema regressed, and a decrease in ICP was observed because of using inhibitors (AZD4017) in the treatment (38). By reducing the aqueous humor production of inhibitors, the intraocular pressure is also lowered (39).

\section{Surgical Treatment}

In patients with IIH, surgical treatment options include optic nerve sheath fenestration (ONSF), venous sinus stenting (VSS), ventriculoperitoneal (Vp) and lumboperitoneal (Lp) shunt, and bariatric surgery. These options are used in patients who are unresponsive to medical treatment or whose symptoms continue to worsen despite treatment. Besides these problems, surgical methods may be preferred in patients with a fulminant course, rapidly decreasing vision or initially developing severe vision loss. The choice and timing of surgical treatment are controversial as there are no adequate prospective randomized-controlled studies comparing these treatments. The selection is often made based on the center's available resources and surgeon's experience. However, in the presence of more than one option, the decision should be made by considering the patient's findings and severity of vision loss. For example, in a patient who presents with vision loss and no signs of IIP syndrome other than papilledema, the best option is ONSF, while in a patient presenting with findings of increased ICP, such as severe headache, pulsatile tinnitus, and diplopia, in addition to papilledema, a shunt or stent may be preferred (33).

\section{a. Optic nerve sheath fenestration:}

ONSF was first described by DeWecker (1872) and Carter (1887). Medial, lateral, combined, superior, and endonasal methods have been used to open various slits or dural windows in the edematous optic nerve sheath (40). It is a recommended treatment method in patients with $\mathrm{IIH}$, who are refractory to medical treatment and present with severe vision loss and mild headache symptoms (41). The exact mechanism by which ONSF causes improvement in papilledema and visual parameters is unknown. The first hypothesis is that ONSF induces fibrosis by blocking the CSF flow between the subarachnoid space around the optic nerve and intracranial subarachnoid space, and the other theory is that ONSF creates a dural fistula that allows CSF drainage and thus relieves the intracranial hypertension (42). The intracranial pressure may decrease slightly after ONSF, but the magnitude and duration of the decrease have not been determined (43). In some patients, unilateral ONSF can improve papilledema and visual function in the contralateral eye (33).

ONSF is more likely to improve visual functions when performed in the acute phase rather than the chronic phase of papilledema (44). Stabilization or improvement in visual acuity was achieved in $95 \%$ of the operated eyes of patients with $\mathrm{IIH}$ (45). Many patients require medical treatment for $\mathrm{IIH}$ and bilateral sequential ONSF. Although approximately half of the patients show postoperative improvement in their headaches, this probability is lower with shunt procedures, and more than one-third of patients may need to undergo a subsequent shunt operation (45). Therefore, this option is ineffective in patients with only severe and restrictive headache without visual loss. Potential complications of ONSF include temporary or permanent worsening of visual function (due to optic nerve trauma or central retinal artery occlusion), tonic pupil, and diplopia (33). 


\section{b. Venous sinus stenting:}

Recently, developments in imaging techniques and better demonstration of morphological abnormalities have created excitement and highlighted the role of venous occlusion in the etiology of IIH (46). It is unclear whether stenosis is the cause or consequence of increased ICP. Stenosis increases pressure through venous hypertension and decreased CSF absorption or external compression of the veins $(47,48)$. While the incidence of transverse sinus stenosis in the general population is $6.8 \%$, its incidence in IIH varies between $10 \%$ and $90 \%$ according to the rate of use of magnetic resonance venography (49). Even if patients have bilateral stenosis, unilateral VSS is often preferred, and the stent is usually placed on the side with a higher degree of stenosis or in the dominant transverse/sigmoid sinus (50).

Many publications show positive results of transverse sinus stenting $(47,48)$. In a study by Ahmed et al. (51), papilledema improved in all 52 patients treated with stent, and venous pressure returned to normal. Recurrent headache was associated with stenosis in the area adjacent to the stent in six patients, who underwent a stent revision. In the follow-ups, it was observed that all complaints related to IIH disappeared in 49 of 52 patients. However, when the general evaluation of endovascular stenting was made, the short duration of well-being and high recurrence rates in patients were disappointing. This failure was explained by the fact that the causes of sinus thrombosis were not adequately addressed. Intrastent stenosis and occlusions result from intrastent thrombosis. The incidence of intrastent thrombosis decreases with short-term dual antiplatelet therapy (50). Non-stent stenosis may occur due to increased pressure on the sinus, and its treatment is controversial because its pathophysiology remains unclear (52).

Radiological evidence of sinus stenosis alone is insufficient for stenting. To obtain effective clinical responses after the procedure, the severe pressure gradient on the sinuses should be physiologically demonstrated by a digital subtraction venography and manometry (53). It has been reported in many studies that stenting is performed in patients with a pressure gradient of $10 \mathrm{mmHg}$ or above (54). Complications of VSS are rare and are mostly related to the angiography procedure itself, such as femoral pseudoaneurysms (52). Among the serious complications are bilateral cerebellar hematoma and obstructive hydrocephalus (55). A reported case of death was associated with venous perforation due to a wide guidewire, and the use of more flexible and easily deployable stents was recommended in the procedure (55). Today, there is a debate about whether this method is an effective option.

\section{c. Shunt operations:}

CSF shunt operations may be preferred in patients where rapid correction of symptoms due to IIP and papilledema is required (56). Lp and $\mathrm{Vp}$ shunts are the most commonly used shunt procedures when treating IIH. Stereotactic Vp shunt is often preferred because of its lower complications' rate. In patients where peritoneal drainage is contraindicated, such as patients with intraperitoneal adhesions, ventriculoatrial and ventriculojugular shunts may also be preferred (33).

In a study by McGirt et al. (57), a significant decrease in postprocedural headaches was observed in 40 of 42 patients, who underwent shunt operation, and headaches recurred at the end of the first year in approximately $20 \%$ and at the end of the third year in $50 \%$. Shunt revisions are often needed because of shunt complications, such as infection, occlusion, and tube displacement (58). Although shunt operations are the oldest surgical intervention used to treat $\mathrm{IIH}$ and have the highest surgical experience, they are not recommended as the first choice for patients with isolated resistant headaches and those with mild or moderate visual loss at presentation, due to the risk of complications, need for revision, and possibility of recurrence (10).

\section{d. Bariatric surgery:}

Bariatric surgery methods can be considered in patients who cannot lose enough weight with a low-calorie diet, lifestyle changes, and exercise (59). Different bariatric surgical approaches can be performed either using an open technique or laparoscopically, such as Roux-en-Y gastric bypass, laparoscopic adjustable gastric band, and laparoscopic sleeve gastrectomy.

Roux-en-Y gastric bypass surgery provides an effective weight loss. However, its complications include malabsorption of substances, such as calcium, B12, folate, iron, and vitamin D, and mortality. In sleeve gastrectomy surgeries, which are much safer, weight loss is often short-lived (60). In a study in which 12 reviews were evaluated, it was reported that BMI decreased from $47.4 \mathrm{~kg} / \mathrm{m}^{2}$ to $33.7 \mathrm{~kg} / \mathrm{m}^{2}$, headache decreased by $90 \%$, papilledema decreased by $54 \%$, visual complaints decreased by $18 \%$, and tinnitus decreased by $54 \%$ after bariatric surgery, performed using different techniques, in 39 patients, of which 38 were women, with a mean age of 32.5 years (61).

The exact indications for bariatric surgery in IIH are unclear. It may be appropriate for obese patients whose symptoms persist despite medical treatment and those in whom surgical interventions (such as ONSF and shunt operation) have failed (20). All bariatric surgical methods cause more weight loss compared with non-surgical interventions (62). The fact that weight loss is the only disease-modifying treatment option and bariatric surgery has a lower cost and is safer than shunt operations may make bariatric surgery more prominent among IIH treatment options in the coming years $(63,64)$.

\section{e. Bridging treatment options:}

When it is impossible to perform the previously described surgical methods in cases such as the patient cannot be transferred to the appropriate center, patients with a fulminant course, until the level of adequate medical treatment is reached, or patients refusing permanent surgical treatments, methods that will temporarily reduce CSF circulation can be used in addition to a medical treatment to reduce ICP. Such methods are arranged from less invasive to more invasive as follows: recurrent LP, lumbar drainage, and extraventricular drainage (44).

Repeated evacuations with LP were used more intensively in a previous period. They are extremely wearisome for patients, have limited benefits, and are not routinely used today. However, besides its diagnostic role, LP may also have a therapeutic temporary role to preserve visual functions, especially in patients with IIH with a fulminant course. Patients had a complete remission after a single LP (65). In some patients, withdrawing 20-30 $\mathrm{ml}$ of CSF is sufficient to reopen the collapsed transverse sinus and decreases the cerebral venous pressure at a rate that can change the CSF circulation (5). Even if CSF is withdrawn until the closing pressure returns to normal with LP, the effects of repeated LP are short-lived due to the high CSF production rate (approximately $15 \mathrm{ml} /$ hour) (66). 
Lumbar drainage may be preferred when there is no benefit from repeated LP. After withdrawing CSF until the intracranial pressure is within the normal range, the drainage is adjusted to $15 \mathrm{ml} /$ hour, and a clamping attempt is recommended approximately $36-48 \mathrm{~h}$ after the placement of the drain. The persistence or recurrence of complaints despite adequate medical treatment when the drain is clamped indicates the need for permanent surgical treatment (67). Bacterial meningitis and symptomatic subdural or subarachnoid hemorrhage are the most common complications of drainage (68).

Extraventricular drainage may be preferred when repeated LPs and lumbar drainage are ineffective. Since extraventricular drainage can be applied quickly and the risk of complications after a successful procedure is low, it can be used as a transitional treatment, especially in patients who are scheduled for a $\mathrm{Vp}$ shunt (69).

\section{Comparison of Surgical Methods}

Although the number of studies on surgical interventions for IIH has almost tripled since 2014, there are no prospective randomized-controlled studies comparing the different methods.

In the most comprehensive review in the literature by Kalyvas et al. (53), 2008 studies, involving patients with IIH who underwent surgical intervention between 1985 and 2019, were evaluated, and four surgical approach methods were compared in 109 studies, three of which were prospective, including 75 retrospective studies and 31 case reports (Table 5). While VSS constitutes the largest subgroup in which reliable results can be obtained, the small number of patients in the bariatric surgery subgroup is insufficient to make reliable conclusions and comparisons. In that study, VSS appears to be the most effective surgical intervention in terms of improvement of papilledema, visual field, and visual acuity. Because ONSF cannot treat headaches effectively, it is the preferred intervention method, especially in patients with insignificant headaches who develop rapid or severe visual loss (53).

The rate of treatment failure, defined as worsening of visual complaints or recurrence of headache in a patient whose symptoms have improved after surgery, is lowest in ONSF and highest in shunt operations. When evaluated in terms of general complications, VSS (9\%) and ONSF $(20 \%)$ seem to have the worst profile. However, notably, ONSF has the lowest rate of serious complications (2.2\%), followed by VSS (2.3\%) (53).

In patients resistant to the highest tolerable dose of medical therapy and experience progressive vision loss, the decision of the appropriate surgical method should be made based on the complication rates of the procedure.

\section{Conclusion}

Although IIH has been known for many years, difficulty in making an accurate diagnosis and low patient compliance to treatment are challenging for physicians. In the last decade, knowledge on the pathophysiology, symptoms, and course of the disease has increased. However, it is important to be meticulous in terms of diagnosis and classification of accompanying symptoms. It is absolutely impossible to diagnose IIH without performing LP, and contrary attitudes may create medicolegal problems for physicians and patients.

In this disease, where the main goal is to preserve visual functions, the $10 \%$ rate of development of permanent vision loss requires appropriate treatment options to be started at the appropriate time. Due to the high risk of recurrence, it is recommended that patients be followed up closely for a long time with BMI control, visual field test, visual acuity, and fundus evaluation.

\section{Ethics}

Peer-review: Externally and internally peer-reviewed.

\section{Authorship Contributions}

Concept: B.B., N.Ç., Design: B.B., N.Ç., B.R.H.B., Data Collection or Processing: B.B. B.R.H.B., Analysis or Interpretation: B.B., N.Ç., Literature Search: B.B. B.R.H.B., Writing: B.R.H.B., B.B., N.Ç.

Conflict of Interest: No conflict of interest was declared by the authors.

Financial Disclosure: The authors declared that this study received no financial support.

\section{References}

1. Friedman DI, Liu GT, Digre KB. Revised diagnostic criteria for the pseudotumor cerebri syndrome in adults and children. Neurology 2013;81:1159-1165.

2. Yunisova G, Güngör I, Kocasoy Orhan E, Baykan B. Stabbing headache as the presenting symptom of idiopathic intracranial hypertension. Headache 2017;57:1152-1153.

3. Mollan SP, Ali F, Hassan-Smith G, et al. Evolving evidence in adult idiopathic intracranial hypertension: Pathophysiology and management. J Neurol Neurosurg Psychiatry 2016;87:982-992.

4. Ekizoglu E, Baykan B, Orhan EK, Ertas M. The analysis of allodynia in patients with idiopathic intracranial hypertension. Cephalalgia 2012;32:1049-1058.

5. Toscano S, Lo Fermo S, Reggio E, et al. An update on idiopathic intracranial hypertension in adults: a look at pathophysiology, diagnostic approach and management. J Neurol 2021;268:3249-3268.

6. Boddu S, Dinkin M, Suurna M, et al. Resolution of pulsatile tinnitus after venous sinus stenting in patients with Idiopathic Intracranial Hypertension. PLoS One 2016;11:e0164466.

7. Wall M, Kupersmith MJ, Kieburtz KD, et al. The idiopathic intracranial hypertension treatment trial clinical profile at baseline. JAMA Neurol 2014;71:693-701.

8. Bidot S, Bruce BB, Saindane AM, Newman NJ, Biousse V. Asymmetric papilledema in idiopathic intracranial hypertension. J Neuroophthalmol 2015;35:31-36.

9. Wall M, Falardeau J, Fletcher WA, et al. Risk factors for poor visual outcome in patients with idiopathic intracranial hypertension. Neurol 2015;85:799805 .

10. Thurtell MJ. Idiopathic intracranial hypertension. Continuum (Minneap Minn) 2019;25:1289-1309.

11. Tata G, Kisabay A, Gokcay F, Celebisoy N. Idiopathic intracranial hypertension: Are there predictors for visual outcome or recurrences? Clin Neurol Neurosurg 2019;183:105378.

12. Hilely A, Hecht I, Goldenberg-Cohen N, Leiba H. Long-term follow-up of pseudotumor cerebri syndrome in prepubertal children, adolescents, and adults. Pediatr Neurol 2019;101:57-63.

13. $\mathrm{Ng} \mathrm{M}$, Fleming $\mathrm{T}$, Robinson $\mathrm{M}$, et al. Global, regional, and national prevalence of overweight and obesity in children and adults during 19802013: A systematic analysis for the Global Burden of Disease Study 2013. Lancet 2014;384:766-781.

14. Chen J, Wall M. Epidemiology and risk factors for idiopathic intracranial hypertension. Int Ophthalmol Clin 2014;54:1-11.

15. Mallery RM, Rehmani OF, Woo JH, et al. Utility of magnetic resonance imaging features for improving the diagnosis of idiopathic intracranial hypertension without papilledema. J Neuroophthalmol 2019;39:299-307.

16. Bono F, Cristiano D, Mastrandrea C, et al. The upper limit of normal CSF opening pressure is related to bilateral transverse sinus stenosis in headache sufferers. Cephalalgia 2010;30:145-151. 
17. Baykan B, Ekizoğlu E, Altiokka G. An update on the pathophysiology of idiopathic intracranial hypertension alias pseudotumor cerebri. Agri 2015;27:63-72.

18. Zierle-Ghosh A, Jan A. Physiology, Body Mass Index. 2021 Jul 22. In: StatPearls [Internet]. Treasure Island (FL): StatPearls Publishing; 2021 Jan-.

19. Mollan SP, Ali F, Hassan-Smith G, et al. Evolving evidence in adult idiopathic intracranial hypertension: Pathophysiology and management. J Neurol Neurosurg Psychiatry 2016;87:982-992.

20. Subramaniam S, Fletcher WA. Obesity and weight loss in idiopathic intracranial hypertension: a narrative review. J Neuroophthalmol 2017;37:197-205.

21. Hornby C, Mollan SP, Botfield H, O'Reilly MW, Sinclair AJ. Metabolic concepts in idiopathic intracranial hypertension and their potential for therapeutic intervention. J Neuroophthalmol 2018;38:522-530.

22. Berdahl JP, Fleischman D, Zaydlarova J, et al. Body mass index has a linear relationship with cerebrospinal fluid pressure. Invest Ophthalmol Vis Sci 2012;53:1422-1427.

23. Sinclair AJ, Burdon MA, Nightingale PG, et al. Low energy diet and intracranial pressure in women with idiopathic intracranial hypertension: prospective cohort study. BMJ 2010;341:c2701.

24. Kesler A, Hadayer A, Goldhammer Y, Almog Y, Korczyn AD. Idiopathic intracranial hypertension: risk of recurrences. Neurology 2004;63:17371739.

25. Shah VA, Kardon RH, Lee AG, Corbett JJ, Wall M. Long-term follow-up of idiopathic intracranial hypertension: the Iowa experience. Neurology 2008;70:634-640.

26. Ko MW, Chang SC, Ridha MA, et al. Weight gain and recurrence in idiopathic intracranial hypertension: a case-control study. Neurology 2011;76:1564-1567.

27. Friedman DI. Contemporary management of the pseudotumor cerebri syndrome. Expert Rev Neurother 2019;19:881-893.

28. Wall M, McDermott MP, Kieburtz KD, et al. Effect of acetazolamide on visual function in patients with idiopathic intracranial hypertension and mild visual loss: The idiopathic intracranial hypertension treatment trial. J Am Med Assoc 2014;311:1641-1651.

29. Ten Hove MW, Friedman DI, Patel AD, et al. Safety and tolerability of acetazolamide in the idiopathic intracranial hypertension treatment trial. J Neuroophthalmol 2016;36:13-19.

30. Falardeau J, Lobb BM, Golden S, Maxfield SD, Tanne E. The use of acetazolamide during pregnancy in intracranial hypertension patients. J Neuroophthalmol 2013;33:9-12.

31. Çelebisoy N, Gökçay F, Şirin H, Akyürekli Ö. Treatment of idiopathic intracranial hypertension: Topiramate vs acetazolamide, an open-label study. Acta Neurol Scand 2007;116:322-327.

32. Dodick DW. Migraine. Lancet 2018;391:1315-1330.

33. Thurtell MJ, Kawasaki A. Update in the management of idiopathic intracranial hypertension. Neurol Clin 2021;39:147-161.

34. Thambisetty M, Lavin PJ, Newman NJ, Biousse V. Fulminant idiopathic intracranial hypertension. Neurology 2007;68:229-232.

35. Botfield HF, Uldall MS, Westgate CSJ, et al. A glucagon-like peptide-1 receptor agonist reduces intracranial pressure in a rat model of hydrocephalus. Sci Transl Med 2017;9:eaan0972.

36. Markey KA, Uldall $\mathrm{M}$, Botfield $\mathrm{H}$, et al. Idiopathic intracranial hypertension, hormones, and $11 \beta$-hydroxysteroid dehydrogenases. J Pain Res 2016;9:223-232.

37. Gathercole LL, Lavery GG, Morgan SA, et al. 11ß-hydroxysteroid dehydrogenase 1: translational and therapeutic aspects. Endocr Rev 2013;34:525-555.

38. Markey K, Mitchell J, Botfield H, et al. 1b-Hydroxysteroid dehydrogenase type 1 inhibition in idiopathic intracranial hypertension: a double-blind randomized controlled trial. Brain Commun 2020;2:fcz050.

39. Rauz S, Cheung CMG, Wood PJ, et al. Inhibition of $11 \beta$-hydroxysteroid dehydrogenase type of 1 lowers intraocular pressure in patients with ocular hypertension. QJM 2003;96:481-490.

40. Gilbert AL, Chwalisz B, Mallery R. Complications of optic nerve sheath fenestration as a treatment for idiopathic intracranial hypertension. Semin Ophthalmol 2018;33:36-41.

41. Friedman DI. The pseudotumor cerebri syndrome. Neurol Clin 2014;32:363-396.
42. Banta JT, Farris BK. Pseudotumor cerebri and optic nerve sheath decompression. Ophthalmology 2000;107:1907-1912.

43. Killer HE, Jaggi GP, Flammer J, et al. Cerebrospinal fluid dynamics between the intracranial and the subarachnoid space of the optic nerve. Is it always bidirectional? Brain 2007;130:514-520.

44. Bouffard MA. Fulminant idiopathic intracranial hypertension. Curr Neurol Neurosci Rep 2020;20:8.

45. Satti SR, Leishangthem L, Chaudry MI. Meta-analysis of csf diversion procedures and dural venous sinus stenting in the setting of medically refractory idiopathic intracranial hypertension. Am J Neuroradiol 2015;36:1899-1904.

46. Owler BK, Besser M. Extradural hematoma causing venous sinus obstruction and pseudotumor cerebri syndrome. Child's Nerv Syst 2005;21:262-264.

47. Bussière $\mathrm{M}$, Falero $\mathrm{R}$, Nicolle $\mathrm{D}$, et al. Unilateral transverse sinus stenting of patients with idiopathic intracranial hypertension. Am J Neuroradiol 2010;31:645-650.

48. Kumpe DA, Bennett JL, Seinfeld J, et al. Dural sinus stent placement for idiopathic intracranial hypertension: clinical article. J Neurosurg 2012;116:538-548.

49. Elder BD, Rory Goodwin C, Kosztowski TA, et al. Venous sinus stenting is a valuable treatment for fulminant idiopathic intracranial hypertension. J Clin Neurosci 2015;22:685-689.

50. Kanagalingam S, Subramanian PS. Cerebral venous sinus stenting for pseudotumor cerebri: a review Saudi J Ophthalmol 2015;29:3-8.

51. Ahmed RM, Wilkinson M, Parker GD, et al. Transverse sinus stenting for idiopathic intracranial hypertension: A review of 52 patients and of model predictions. Am J Neuroradiol 2011;32:1408-1414.

52. Starke RM, Wang T, Ding D, et al. Endovascular treatment of venous sinus stenosis in idiopathic intracranial hypertension: complications, neurological outcomes, and radiographic results. ScientificWorldJournal 2015;2015:140408.

53. Kalyvas A, Neromyliotis E, Koutsarnakis C, et al. A systematic review of surgical treatments of idiopathic intracranial hypertension (IIH). Neurosurg Rev 2021;44:773-792.

54. Giridharan N, Patel SK, Ojugbeli A, et al. Understanding the complex pathophysiology of idiopathic intracranial hypertension and the evolving role of venous sinus stenting: a comprehensive review of the literature. Neurosurg Focus 2018;45:E10.

55. Lavoie P, Audet MÈ, Gariepy JL, et al. Severe cerebellar hemorrhage following transverse sinus stenting for idiopathic intracranial hypertension. Interv Neuroradiol 2018;24:100-105.

56. Menger RP, Connor DE, Thakur JD, et al. A comparison of lumboperitoneal and ventriculoperitoneal shunting for idiopathic intracranial hypertension: an analysis of economic impact and complications using the nationwide inpatient sample. Neurosurg Focus 2014;37:E4.

57. McGirt MJ, Woodworth G, Thomas G, et al. Cerebrospinal fluid shunt placement for pseudotumor cerebri-associated intractable headache: predictors of treatment response and an analysis of long-term outcomes J Neurosurg 2004;101:627-632.

58. Kalyvas AV, Hughes M, Koutsarnakis C, et al. Efficacy, complications and cost of surgical interventions for idiopathic intracranial hypertension: a systematic review of the literature. Acta Neurochir (Wien) 2017;159:33-49.

59. Fraser JA, Bruce BB, Rucker J, et al. Risk factors for idiopathic intracranial hypertension in men: A case-control study. J Neurol Sci 2010;290:86-89.

60. Breznikar B, Dinevski D. Bariatric surgery for morbid obesity: Pre-operative assessment, surgical techniques and post-operative monitoring. J Int Med Res 2009;37:1632-1645.

61. Sun WYL, Switzer NJ, Dang JT, et al. Idiopathic intracranial hypertension and bariatric surgery: A systematic review. Can J Surg 2020;63:E123-E128.

62. Colquitt JL, Pickett K, Loveman E, Frampton GK. Surgery for weight loss in adults. Cochrane Database Syst Rev 2014:CD003641.

63. Mollan SP, Davies B, Silver NC, et al. Idiopathic intracranial hypertension: consensus guidelines on management. J Neurol Neurosurg Psychiatry 2018;89:1088-1100.

64. Merola J, Selezneva L, Perkins R, et al. Cerebrospinal fluid diversion versus bariatric surgery in the management of idiopathic intracranial hypertension. Br J Neurosurg 2020;34:9-12. 
65. De Simone R, Marano E, Fiorillo C, et al. Sudden re-opening of collapsed transverse sinuses and longstanding clinical remission after a single lumbar puncture in a case of idiopathic intracranial hypertension. Pathogenetic implications. Neurol Sci 2005;25:342-344.

66. Gates P, McNeill P. A possible role for temporary lumbar drainage in the management of idiopathic intracranial hypertension. Neuroophthalmol 2016;40:277-280.

67. Bir LS, Degirmenci E, Erdogan C, Bilgin S, Coşkun E. Rapid recovery of visual acuity after lumboperitoneal shunt operation in malignant idiopathic intracranial hypertension. Case Rep Ophthalmol Med 2011;2011:405838.

68. Governale LS, Fein N, Logsdon J, Black PM. Techniques and complications of external lumbar drainage for normal pressure hydrocephalus. Neurosurgery 2008;63:378-384.

69. Binz DD, Toussaint LG, Friedman JA. Hemorrhagic complications of ventriculostomy placement: a meta-analysis. Neurocrit Care 2009;10:253256. 